\title{
CONTACT ANGLE MEASUREMENT OF DENTAL RESTORATIVE MATERIALS BY DROP PROFILE IMAGE ANALYSIS
}

\author{
H. D. K. Yulianto dan M. Rinastiti \\ Faculty of DentistryUniversitasGadjahMada \\ Email: dedykusuma@ugm. ac.id
}

\begin{abstract}
ABSTRAK
Kemampuan adhesi mikroba awal untuk gigi restorative komposit permukaan dipengaruhi oleh keterbasahan permukaan bahan. Metode yang umum untuk mengevaluasi keterbasahan permukaan bahan adalah pengukuran sudut kontak. Metode konvensional yang ada untuk mengukur sudut kontak dilakukan dengan cara sudut kontak (CA) perangkat-Goniometer yang kurang praktis diterapkan dalam situasi klinis. Oleh karena itu, metode yang lebih praktis dan dapat diterapkan diperlukan untuk mengukur sudut kontak dalam keadaan klinis. Untuk membandingkan antara sudut kontak diukur dengan cara CA-goniometer perangkat dan baru praktis metode analisis penurunan profil gambar. Selain karena ada dua formula yang berbeda yang dapat digunakan untuk menghitung nilai sudut kontak dari gambar profil drop, maka kita juga perlu mengevaluasi formula yang lebih handal untuk digunakan. Pengujian dilakukan dengan menggunakan tiga cakram komposit (Clearfill-Kuraray Medis, Inc. ) sample dan air deionisasi untuk prosedur pengukuran yang berbeda. Cairan satu tetes $3 \mu l$ dijatuhkan pada permukaan cakram komposit dan gambar profil penurunan ditangkap dengan cara disesuaikan perangkat buatan terhubung dengan kamera digital. Dua formula yang berbeda yang digunakan untuk menghitung nilai kontak sudut dari gambar profil drop, bernama "linier persamaan gradien" dan "garis tangensial". Nilai sudut kontak yang diperoleh dari dua formula yang berbeda dibandingkan dengan nilai yang diperoleh dari metode konvensional secara deskriptif. Persentase perbedaan antara nilai sudut kontak dihitung dengan rumus kedua ("persamaan linier gradien" dan "garis tangensial") dan yang dihitung dengan cara CA-goniometer adalah masing-masing 20,56\% dan 3,51\%. Hal ini jelas menunjukkan bahwa nilai yang diperoleh oleh "garis tangensial" formula memiliki perbedaan persentase yang lebih kecil dibandingkan dengan yang diperoleh "linier persamaan gradien" formula. Di antara dua formula yang berbeda, itu menegaskan bahwa nilai sudut kontak dihitung dengan "garis tangensial" formula memiliki kesamaan lebih dekat dengan nilai yang diperoleh dari CA-goniometer. Hasil ini mengkonfirmasikan bahwa baru praktis metode analisis citra profil drop menjanjikan untuk digunakan dalam mengukur nilai sudut kontak dalam keadaan klinis. Terkait dengan analisis citra profil drop, "garis tangensial" formula lebih akurat dibandingkan dengan "persamaan gradient linier" formula.
\end{abstract}

Kata Kunci: Sudut kontak, Adhesi Mikroba, Bahan restorasi gigi.

\section{ABSTRACT}

The capability of initial microbial adhesion to dental restorative composites surface is influenced by surface wettability of materials. The common method to evaluate surface wettability of materials is contact angle measurement. The existing conventional method to measure the contact angle is carried out by means ofcontact angle (CA)-Goniometer device which is less practically applicable in clinical circumstances. Therefore,the more 
practicaland applicable method is neededto measure the contact angle in clinical circumstances. To compare between the contact angle measured by means of CA-Goniometer device and new practically method by drop profile image analysis. In addition due to there were two different formulas that can be used to calculate the contact angle value from the drop profile image, then we also need to evaluate the formula which is more reliable to be used. Tests were carried out using three composite discs (Clearfill-Kuraray Medical, Inc. ) sample and deionised water for different measurement procedures. One drop $3 \mu \mathrm{l}$ liquid wasdropped on the surface of the composite discs and the drop profile imagewascaptured by means of customized home-made device connected with digital camera. Two different formulas were used to calculate the contact angle value from the drop profile image, named "linier gradient equation" and "tangential line". The contact angle values obtained from two different formulas were compared with the value obtained fromthe conventional method descriptively. The difference percentage between the contact angle value calculated by the both formula ("linier gradient equation" and "tangential line") and those calculated by means of the CA-Goniometer is $20,56 \%$ and 3,51\% respectively. It is obviously demonstrated that the value obtained by the "tangential line" formula has a smaller difference percentage compared with those obtained by the "linier equation gradient" formula. Among two different formulas, it is confirmed that the contact angle value calculated with "tangential line" formula has closer similarity with the value obtained from the CA-Goniometer.

Keywords: Contact angle, Microbial adhesion, Dentalrestorative materials.

\section{INTRODUCTION}

Dental caries is a major cause of tooth decay for most of Indonesia's population. The main cause of dental caries is the attachment of bacteria that form biofilms on the surface of hard and soft tissues in the oral cavity (Khalichi et al. , 2004). Currently, the composite resin is still the main option for repair dental hard tissue damage due to the process of caries. The composites not only brought a change in materials and techniques but also a change in treatment philosophy called minimal invasive dentistry (Roeters et al. , 2004; Murdoch et al. , 2003; Tyas et al. , 2000). Composites allow the possibility of preserving sound tooth structure during cavity preparation (Leinfelder, 1997). Composites resins have the ability to bind to the dental hard tissues through the adhesive material (Imazato, 2003). Furthermore, composite resin represents a significant aesthetic treatment option, enabling the fabrication of restorations with a natural appearance (Gordan, 2003). Although marked improvements have been noted in terms of physical and mechanical properties during the last 10-20 years, several factors in dynamic oral environment can degrade the composite matrix via three principal modes, i. e. : mechanical degradation, physical degradation and chemical degradation (Oilo, 1992; Winkler, 1991). Dynamically changes of oral environment are influenced by food components, beverages, temperature changes, chewing, saliva and bacterial activity. Those factors have an important role in the degradation of compositesthat clinically resulted in failure, such as: discoloration, wear, ditching at the margins, delamination or simply fracture which may result in secondary dental caries (Roulet, 1988: 101-113; Swift, 1987: 584-588).

The intraoral biofilm that forms naturally on dental restorative materials is dental plaque, a diverse community of bacteria embedded in an organic matrix. Plaque development involves the formation of pellicle, early microbial colonization, and maturation leading to a dynamic equilibrium. Major shift in equilibrium leads to disease of hard and soft tissue. The biofilm adsorption on surface depends on the biologic flow rate, type of interfacial interaction involved, and attachment strength with the substrate. It has been found that microbial binding strength is lower on hydrophobic surfaces than hydrophilic ones. Polar or non-polar nature, the hydrogenbonding capacity, and the electron donor or acceptor potential seems to control the hydrophilic or hydrophobic character and energetic state of the surfaces (Eliades et al, 2003).

Microorganisms in the oral environment not only form a biofilm on all available surfaces, including hard and soft tissue surfaces, 
but also on biomaterials used for restoration of function or aesthetics (Bouschlicher, 1997: 279-283). Exposure to saliva and biofilm lead to degradation of composite surfaces that may have increased roughness, sometimes accompanied by decreased microhardness and increased exposure of filler particles or matrix swelling (Göpferich, 1996: 103-114; Soderholm, 1981: 1867-1875).

Presence of salivary protein albumin on dental surface inhibits interaction adhesion of bacterial mediated by hydrophobic interaction (Steinberg, 1981). Adhesion and maturation of numerous species of cariogenic bacteria will promote maturation of biofilm. These biofilm will easily trapped on the groove of rough surface that is resulted from degradation process by salivary enzyme like cholinesterase (CE) thereby promoting maturation (Finer et al. , 2004: 22-26). Adhesion of microorganisms to dental resin composite surfaces and the problems that were caused are a matter of concern to the patient and dentist. Biofilms have the potential to act as a chronic source of microbial contamination which may compromise restoration quality and represent a significant health hazard.

Initial microbial adhesion involves nonspesific forces that transfer microorganisms close to the substrate to establish spesific bonding. Coaggregation, coadhesion, release of biosurfactans, production of extracellular matrix polymers, and various competitive reactions are considered important factors for the formation and rapid growth of plaque. The plaque-retention capacity has long been recognized as a major influencing oral health (Eliades et al. ,2003).

The capability of initial microbial adhesion to the composites surface is influenced by surface wettability of materials. The contact angle of liquid drop on the substrate surface measured by means of CA-Goniometer represents valuable parameter in the wettability properties of the materials. An important requirement that must be fulfilled is placing the sample in perfectly horizontal position before dropping the liquid. In such case, where the position of the sample can't be placed as recommended requirement, this method faces some difficulty. For example, in clinical circumstances the material to be tested could be in varying position.

In this research, new method developed by using drop profile image analysis was proposed. The drop profile image can be captured from the sample placed in any varying position. Indeed, the flexibility of sample positionis an important parameter if the measurement will be applied in clinical circumstances. From practical point of view, this new method is suitable to be applied. However, the reliability and validity of the contact angle value resulted from this new method need to be evaluated by comparing it with the result obtained from the existing conventional method. Therefore, the aim of this research is to compare the contact angle value measured by means of CAGoniometer device with the value measured by thedrop profile image analysis. There were two different formulas were used to calculate the contact angle values from the image of the drop profile, named "linier gradient equation" and "tangential line". So that it is also important to evaluate which one among two different formulas is more reliable.

In order to evaluate the reliability and validity of the new developed method, tests on dental restorative composite material (ClearfillKuraray Medical Inc. ) have been performed to obtain the contact angle value. The de-ionized waterwas used as liquid drop. The drop profile image was captured by customized home-made device connected with digital camera. The next step was calculating the contact angle value on the image of the drop profile by means of two different formulas, named "linier gradient equation" formula and "tangential line" formula.

The contact angle measurements for respective method were performed in three composite discs measuring 5 milimeter wide and 2 milimeter thick that have been produced by means of customized PVC mould. Totally, there were threecomposite discs were produced to be tested with three different procedures. 
In order to produce the composite discs, the superficial layer of the mould was covered with $100 \mu \mathrm{m}$ thick translucent mylar strip and pressed to create a smooth surface and to prevent the formation of an oxygen inhibiting layer. The material cured either chemically or by means of a halogen photo-polymerization unit, according to the manufacturer's instructions.

\section{Acquiring the Drop Profile Image}

Sessile drop technique was performed by deposited one drop of $3 \mu 1$ de-ionized wateron surface of the composite disc. The drop profile (interaction between liquid-substrate surfaces) image was captured by means of customized home-made device connected with digital camera as shown in Figure 1.

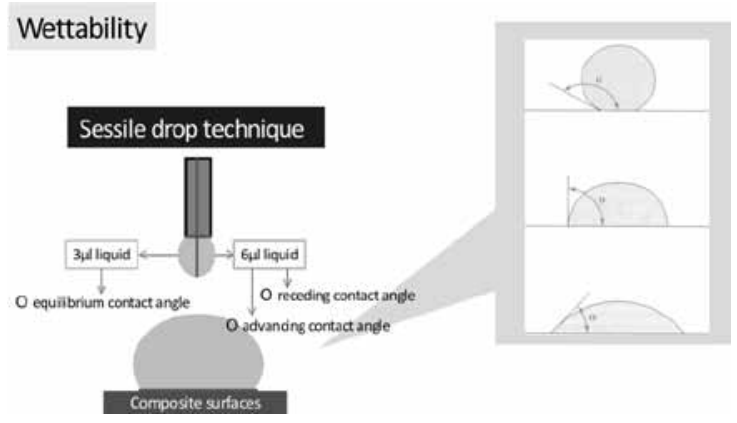

Figure 1.

Schematic Diagram of the Contact Angle Measurement Process

The drop profile images were edited and optimized with image-analysis software before the contact anglewas calculated in order to improve the precision and accuracy of the results. The contact angle was calculated with two different formulas: the "linier gradient equation" formula and and the "tangential line" formula. The contact angles values were compared with the value obtained from the CA-Goniometer descriptively.

\section{Procedures of Measurement}

Three different procedures were used to calculate the contact angle values. One procedure is conventional methods by means of CAGoniometer and the two procedures related with the implementation of the drop profile image analysis by means of two different formulas.

First, Drop profile image analysis using the "linier gradient equation" formulaThe value of contact angle was calculated byusing the "linier gradient equation" formula: $Y=m X$. The ' $X$ ' and ' $Y$ ' coordinate axis were drawn on the image of the drop profile, and then the each value of ' $X$ ' and ' $Y$ ' coordinate were transferred to scatter chart as shown in Figure 2. a. Linier equation and R-squared $\left(\mathrm{R}^{2}\right)$ value on chartwas displayed automatically after ' $\mathrm{X}$ ' $Y$ ' chart was inserted. The value of contact angle $(\theta)$ was calculatedusing the formula $\operatorname{Tan} \theta=\mathrm{R}^{2}$ (Figure 2. $\mathrm{b}$ ).

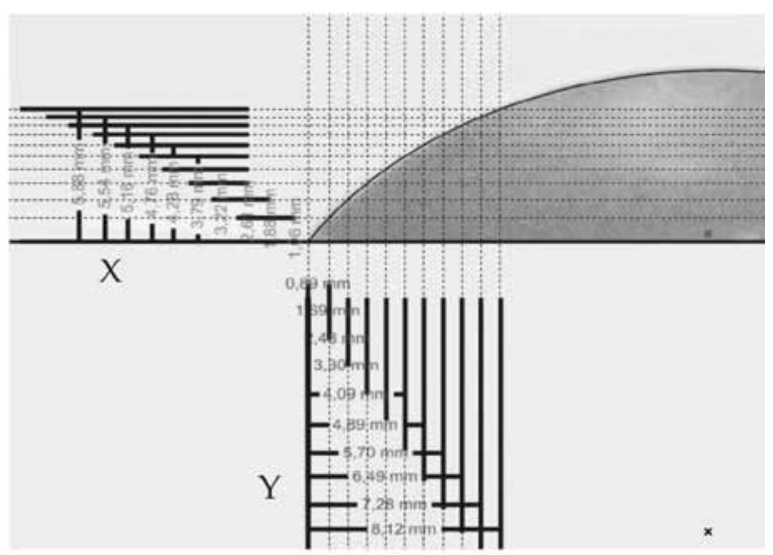

(Figure 2.a)

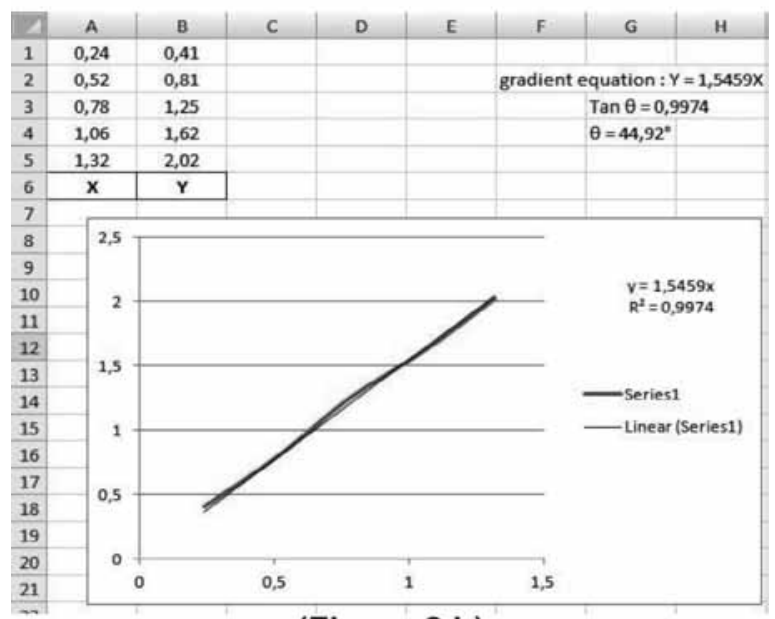

(Figure 2.b)

Figure 2. a. Figure 2. b.

" $X$ " and " $Y$ " coordinate axis. Linier equation and $\mathrm{R}$-squared $\left(\mathrm{R}^{2}\right)$ value. 
Second, Drop profile image analysis using the "tangential line" formula. The drop profile image acquired was optimized before calculating the contact angle value. The next step was drawing the edge of interface between liquid drop and substrate surface on the image of the drop profile. By measuring the height $(\mathrm{h})$ and wide (l) of liquid drop profile on the substrate surface, the value of contact angle was calculated using formula: $\tan \frac{\theta}{2}=\frac{2 h}{l}$ as shown in Figure 3.

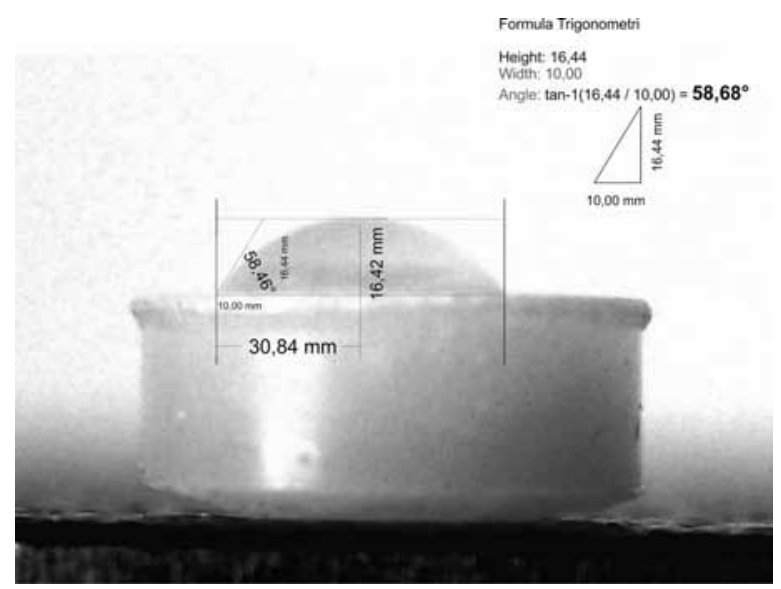

Figure 3

Application of TrigonometryFormula to Calculatethe ContactAngle

Third, The conventional method (by means of the CA-Goniometer device)

The process of measurement was started by deposited one drop of $3 \mu 1$ liquid (de-ionized water) on the surface of the composite disc. The sample was placed in perfectly horizontal position and the liquid was dropped perpendicular to the substrate surface. The device automatically calculated the contact angle based on the analysis of height, width, and volume of the liquid drop on substrate surface.

The contact angle measurements have been performed using the new drop profile image analysis. The results are summarized in the Table 1.
Table 1

Contact AngleI Obtained by DropProfileImage Analysis using the "linier gradient equation" and the "tangential line" Formula

\begin{tabular}{l|l}
\hline \multicolumn{1}{c|}{ Method } & \multicolumn{1}{c}{ Contact angle } \\
\hline $\begin{array}{l}\text { The "linier gradient } \\
\text { equation" formula } \\
\text { The "tangential line" } \\
\text { formula }\end{array}$ & $44,92^{\circ}$ \\
\hline
\end{tabular}

There were different of the contact value obtained from two different formulas as shown in Table 1. In order to evaluate the accuracy and precision among two different formulas, these results need to be compared with the value obtained from conventional method by means of CA-Goniometer.

Measurement process by means of CAGoniometer has been performed according to the procedure which has already previously described. The obtained contact angle measured using CA-Goniometer device was $56,62^{\circ}$ as presented in Figure 4.

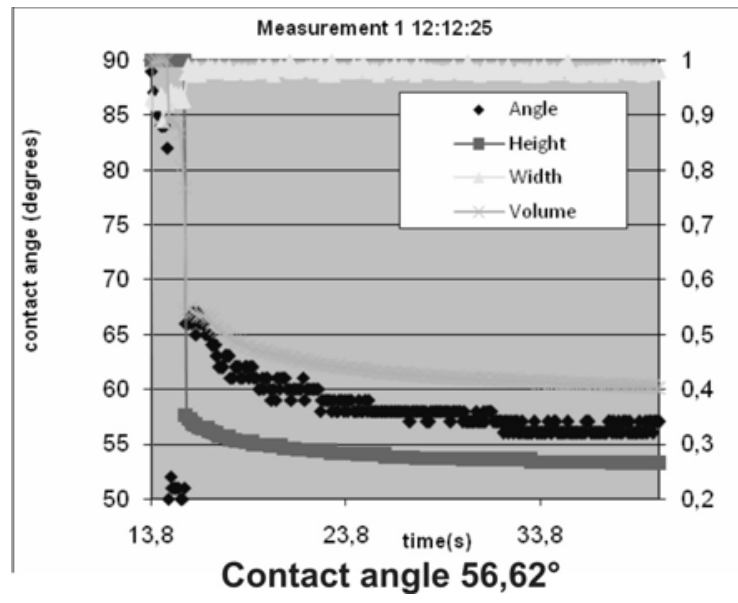

Figure 4

The ContactAngleValueResulted by Means of CA-Goniometer Device

As shown in Figure 4, the contact angle can be precisely obtained because the contact angle value was calculated based on the automated-analysis of height, width, and volume of the liquid on substrate surface. 
The contact angle values measured using three different procedures was compared in table 2. The emphasis was focused to eval-

uate the different percentage between the contact angle values calculated by the two different formulas with the value obtained by means of CA-Goniometer.

Table 2.

Comparison between ContactAngleMeasured by the LinierGradientEquationMethod theTangentMethod and the StandardMethod using CA-GoniometerDevice

\begin{tabular}{c|c|c}
\hline $\begin{array}{c}\text { Linier gradient equation } \\
\text { method }\end{array}$ & $\begin{array}{c}\text { Standard method } \\
\text { (CA-Goniometer device) }\end{array}$ & $\begin{array}{c}\text { Different percentage } \\
(\%)\end{array}$ \\
\hline $44,92^{\circ}$ & $56,62^{\circ}$ & 20,66 \\
\hline \multirow{2}{*}{ Tangent method } & $\begin{array}{c}\text { Standard method } \\
\text { (CA-Goniometer device) }\end{array}$ & $\begin{array}{c}\text { Different percentage } \\
(\%)\end{array}$ \\
\hline $58,68^{\circ}$ & $56,62^{\circ}$ & 3,51 \\
\hline
\end{tabular}

From the Table 2, it is observed that the difference percentage between the contact angle value calculated by the both formulas: "linier gradient equation" and "tangential line" and those calculated by means of CAGoniometer is $20,56 \%$ and 3,51\% respectively. It is obviously demonstrated that the value obtained by the "tangential line" formula has a smaller difference percentage compared with those obtained by the "linier equation gradient" formula. Among two different formulas, it is confirmed that the "tangential line" formula has closer similarity with the value obtained from CA-Goniometer.

\section{DISCUSSION}

Water contact angle illustrate the shape of the liquid drop profilein contact with a surface of solid. Experimental tests were performed in order to evaluate the reliability of the new developed method based on the drop profile image analysis. In addition, the accuracy of the two different formulas which were used to calculate the contact angle values from the drop profile image was observed. As a reference the contact angle value obtained from the conventional method by means of CA-Goniometer was used.

The resultsas presented in the table 2 shows that the contact angle value calculated with the "tangential line" formula has the different percentage less than $5 \%(3,51 \%)$ with the value obtained from the CA-Goniometer. This work confirms experimentally the pos- sibility to measure thewettability of dental restorative composit surface by means of this new developed method.

The contact angle value is an important parameter to predict the wettability properties of the materials. The wettability properties of the surface are an important parameter to predict the capability of microbial adsorption and colonization on the composite surface in biologic environment (Katsikogianni, 2004). It has been found from several studies that surface free energy of the surface influence plaque accumulation (Eliades, 2003). Same amount of protein was adsorbed on high (hydrophobic) and low (hydrophilic) energy surface during the pellicle formation. However, pellicle on low-energy surface (hydrophobic) was thicker and more loosely bound. Moreover, the surface area of plaque accumulation is less on low-energy (hydrophobic) surface than on high-energy (hydrophilic) surfaces (Katsikogianni, 2004).

The contact angle method derived from the drop profile image analysisis probably the most definitive way to determine cell surface hydrophobicity in clinical situation, where the sample does not need to be placed in perfectly horizontal position. The method involves placing a drop of solvent (water, buffer, non-aqueous) on substrate surface. The contact angle (very high for water if the surfaces are hydrophobic) is determined by a series of photographs of the drop profileimage. If the surfaces are hydrophilic, the drop- 
let quickly dissipates, disappearing into the surfaces.

In this experiment we found that the drop profile image analysis using the "tangential line" formula has higher accuracy and more reliable compared with thedrop profile image analysis using the "linier gradient equation" formula. The accuracy of this formula allowed us to affirm that the procedure measurement of the drop profile image analysis using the "tangential line" formula was correct, reliable and sensitive. Therefore, it is likely that the drop profile image analysis using the "tangential line" formula can be used as an alternative way in measuring the contact angle, Moreover, from practical point of view it seems that the drop profile image analysis is more technically practice and have flexibility to be implemented in any clinical circumstances.

\section{CONCLUSION}

This result is confirming that the new practically method by drop profile image analysis is promising to be used in measuring contact angle value in clinical circumstances. Related with the drop profile image analysis, the "tangential line" formula is more accurate compared with the "linier gradient equation" formula.

\section{BIBLIOGRAPHY}

Khalichi, P. , Cvitkovitcha, D. G. , Santerre, J. P. , Effect of composite resin biodegradation products on oral streptococcal growth, Biomaterials 2004; 25: 5467-5472.

Roeters FJM, Opdam NJM, Loomans BAC. The amalgam-free dental school. J Dent 2004;32:371-377.

Murdoch-Kinch MA, McLean ME. Minimally invasive dentistry. J Am Dent Assoc 2003;134:87-95.

Tyas MJ, Anusavice KJ, Frencken JE, Mount GJ. Minimal intervention dentistry a review - FDI Commission Project 1-97. Int Dent J 2000;50:1-12.
Leinfelder K. A conservative approach to placing posterior composite resin restorations. I Am Dent Assoc 1997;127:743-748.

Imazato, S. , Antibacterial properties of resin composites and dentin bonding systems, Dental Materials , 2003; 19: 449-457.

Gordan V, Mjør I, Blum I, Wilson N. Teaching students the repair of resin-based composite restorations: a survey of North American dental schools. J Am Dent Assoc 2003;134:317-323.

Ferracane, J. L. , Elution of leachable components from composite. J Oral Rehabil, 2003; 21:441-452.

Mair, L. , Stolarski, T. , Vowlest, R. , Lloyd, C. , Wear: mechanisms, manifestations and measurement. Report of a workshop. J Dent2003; 24:141-148.

Oilo, G. , Biodegradation of dental composites/glass-ionomer cements. Adv Dent Res 1992; 6:50-54.

Winkler, M. , Greener, E. , Lautenschlager, E. , No-linear in vitro wear of posterior composites with time. Dent Mater 1991; 7:258-262.

Akova, T. , Ozkomur, A. , Uysal, H. , Effect of food-simulating liquids on the mechanical properties of provisional restorative materials. J Dent 2006; 22:1130-1134.

Roulet, J. F. , The problems associated with substituting composite resins for amalgam: a status report on posterior composites. J Dent 1988; 16:101-113.

Swift, E. J. , Wear of composite resins in permanent posterior teeth. J Am Dent Assoc1987; 115:584-588.

Bouschlicher, M. R. , Reindhardt, J. W. , Vargas, M. A. , Surface treatment techniques for resin composite repair. Am J Dent 1997; 10:279-283. 
Fúcio, Z. , Carvalho, F. G. , Sobrinho, L. C. , Sinhoreti, M. , Puppin-Rontani, R. M. , The influence of 30-dayold Streptococcus mutans biofilm on the surface of esthetic restorative materials--An in vitro study. J Dent2008; 36:833-839.

Göpferich, A. , Mechanisms of polymer degradation and erosion. Biomaterials $1996 ; 17: 103-114$.

Soderholm, K. J. , Degradation of glass filler in experimental composites. J Dent Res 1981;60:1867-1875.

Steinberg, D. , Eyal, S. ,Early formation of Streptococcus sobrinus biofilm on various dental restorative materials. Journal of Dentistry2002; 30 47-51.
Finer, Y. , Santerre, J. P. , Salivary esterase activity and its association with the biodegradation of dental composite, J Dent Res 2004; 83(1):: 22-26.

Eliades, G. , Eliade, T. , Brantley, W. A. , Watts, D. C. , Dental Materials In Vivo Aging and Related Phenomena, Quintessence Publishing Co, Inc. 2003.

Katsikogianni, M. And Missirlis, Y. M. , Concise Review of Mechanisms of Bacterial Adhesion to Biomaterials and of Techniques Used in Estimating Bacteria-Material Interactions. European Cells and Materials Vol. 8. 2004 (pages 37-57). 